\title{
THE PUSH FOR THE DIGITALIZATION OF THE COURTS IN THE INDIAN CONSTITUTION, IN THE WAKE OF COVID 19 AND ITS SOCIAL IMPACT
}

\author{
Dr. N Jayarama Reddy \\ Associate Professor of Political Science, GFGC Hoskote, Bengaluru \\ Bengaluru North University, Pin - 562114
}

Article DOI: https://doi.org/10.36713/epra9296

DOI No: 10.36713/epra9296

\begin{abstract}
According to Salmond 'Law may be defined as the body of principles Recognized and applied by the state in the administration of justice. We cannot Imagine our life without the law as it also governs the human conduct in day to day life, In a young democracy like that of democracy the Importance of Judiciary is Magnified, although it has its flaws, the Indian judiciary, especially the higher judiciary, has come through for the citizens more often than not, Things changed when the pandemic that struck the world in 2019 made its presence in India as well. It brought the life to standstill, like everything and everyone the judiciary was also affected by the deadly virus too, there was delay in justice, when the most foundational mandate of an institution is not being fulfilled, and its credibility will be called into question. On the other hand the Pandemic has blessed the judiciary in many ways, Indian judiciary has always lacked behind when it came to digital access, and digitalization was limited only to those people who wanted to access individual cases. The court proceedings were still based on old aged approach, however like it forced everyone hand to embrace a new way of living, the Pandemic forced the Indian judiciary to come out of its shell.
\end{abstract}

\section{INTRODUCTION}

There are three organs of government namely the legislature, the executive and the judiciary, the legislature is responsible for making laws, the executive is responsible for executing the laws and the Judiciary is responsible for Interpretation of various laws and applying it to various cases to settle the disputes. It is Irony of fate that covid19 came at a time when the justice and court administration had reached the threshold of the new era with a lot of groundwork already done, especially during the last decade or so in the area of utilization of Information and communication technologies (ICTs) and the Internet. The e- governance initiatives in justice and court administration were further enhanced after enactment of the Information technology Act 2000. The E-Courts were set up in the country as a crucial part of National e- governance plan (NEGP) launched in 2006. Amid the lockdown caused by the covid19 pandemic, courts in India are adopting digital technology to take up daily hearings. The biggest question before the honourable Supreme Court of India is that whether the Changes made in the Legal system to settle the disputes is only for the temporary basics or has the Covid19 impacted in such a great extent to our Indian legal system that the changes made are permanent in nature.

The Supreme court of India in the leading case of:

$$
\begin{aligned}
& \text { State of Maharashtra } \\
& \text { Vs. } \\
& \text { Praful Desai, on } 1^{\text {st }} \text { April 2003, }
\end{aligned}
$$

The court interpreted the meaning of the word "presence" in a very wider sense and held evidence by the way of video conferencing as evidence in presence of Accused. Hence in the ambit of this paper, the research mainly focuses on the need of digitalization of our Indian legal system, its defects, and how efficiently the courts have adopted the system during the outbreak of the covid19. 


\section{REVIEW OF LITERARURE}

Duhaime's Law Dictionary

"All the rules of conduct that have been approved by the government and which are in force over a certain territory and which must be obeyed by all persons on that territory (ex: The "laws" of Australia).

John Austin

"Province of Jurisprudence Determined"

\section{EXISTING SET-UP FOR DIGITALIZATION IN INDIA}

In the Initial stages of Digitalization, the ECourts mission mode project was launched as a part of National e- governance plan (NeGP); the aim was to make the system Affordable, accessible, cost effective with more of cost management and Reliable. By presence of districts, high courts were secured on National Judicial Data Grid (NJDG). The NJDG (National judicial data Grid) were computerized with the installation of Case Information Software (CIS), which provides a daily status of Litigant's case, the orders of the case and the hearing dates of the case.

\section{ARTIFICIAL INTELLIGENCE}

Artificial Intelligence are being used and one of such modes is through CCTNS ( Crime and Criminal Network Tracking system), this system works by predicting future offenders and hot spots for crime, this system works by Predicting future offenders and hot spots for crimes aiding in public policy. It is being implemented In India at a fast rate since its approval in 2009.Predictive Analytics may also help in Indexing of cases and Research and in filling the probability of wining the cases.

Some of the biggest advantages of using Artificial Intelligence are as follows:

1. Due diligence: It is a method that involves large number of Operating hours as litigators are required to review multiple documents. It involves contract drafting, legal research, so with the introduction of Artificial intelligence tiresome work can be done easily.

2. Technology prediction: Artificial Intelligence software predicts the potential outcome of the pending case or of the new case instituted in front of the court of law. Machine learning systems are capable of grouping a lot of data and this data will be used to develop the predictions

\section{DIGITALIZATION A WAY TO PROVIDE EASE ACCESS TO JUSTICE}

Digitalization has affected our lives in a very diverse ways as it also provides a means to ease to justice, earlier by the use of traditional methods there was delay in justice in many ways like if any case would use to come before the court from that stage to the stage when the decision was given by the court an estimated time period of 5-7 years was taken may be it any case either property related cases, divorce cases, or any criminal matters but after the digitalization of the Indian legal system things were done with ease, the fast track courts are also important part of the Indian legal system which aims at resolving the case and settling the disputes in a very easier manner, the nature of what digital entails has been remained i.e., adoption of digital has been taken several notches above a mere replication of paper process in digital format. A key NITI Aayog has reform and focused upon in the vision is the online dispute resolution (ODR)

Progressive and Disruptive changes in the justice delivery can alter the course of access of justice in a very unprecedented way. The vision has key components that can act as key components that can act as building blocks for ensuring ease of access to justice to a common man.

\section{FALLACIES OF THE DIGITALIZATION OF THE INDIAN JUDICIAL SYSTEM}

In the period of ongoing covid19 and a situation where India is going to suffer again a lockdown, courts are facing a serious problem in the delivery of justice, though courts have adopted the means of videoconferencing in those matters that are serious in nature and need to be resolved, although measures have been taken to maintain the status quo such as limitation period and Interim order, grant of injuctions, a variety of the legal issues remain need of adjudication.

Although there are many advantages of digitalization of the Indian legal system but each and everything has its own pros and cons, same goes with the digitalization of the Indian legal system, of which some of them are as follows:

- There would arise numerous legal problems related to the applicability and authenticity of the identity of witness, evidence produced before the court etc.

- The confidentiality of court proceeding shall be at risk because, the whole setup presuppose the use of technology and varied number of software and tools that possess some or the other kind of threats related to security and privacy of data 


\section{CONCLUSION}

In the era where we are undergoing the continuous lockdown for the third time after the hit of the $2^{\text {nd }}$ wave , the situation throughout the country is becoming even more serious day by day, people are suffering from various financial loss and various economical, social issues the most important pillar of the country the Indian legal system is also suffering from various problems which need to be solved or the result would lead to injustice because of which a person who is not guilty will be punished and the person who has actually done a crime will be not punished, to avoid all these problems the courts should properly function which can only be done if there is digitalization of the Indian judiciary system during the outbreak of the pandemic situation. Providing justice is not an easy task, this could be only possible during the times of outgoing COVID19 by means of the system of digitalization as only people would regain their sense of confidence once again in the judiciary, It's the time to bring changes, nothing can be changed within a day it's a slow and time consuming process but if there are some changes brought every day the entire legal system will definitely be perfect

\section{REFRENCES}

1. https://government.economictimes.indiatimes.com/new s/digital-india/courts-adopting-digital-technologyrapidly-amid-covid-19-ravi-shankar-prasad/77070087

2. https://lawlex.org/lex-pedia/fallacies-of-digitizationof-judicial-system-of-india/21050

3. https://blog.ipleaders.in/artificial-intelligence-respectindian-judicial-system/

4. https://www.financialexpress.com/opinion/e-courtssupreme-courts-digitalisation-vision-will-ease-accessto-justice/2258945/ 